Article

\title{
Characterization of New Sustainable Acoustic Solutions in a Reduced Sized Transmission Chamber
}

\author{
Romina del Rey@, Jesús Alba, Juan C. Rodríguez *®i and Laura Bertó \\ Centro de Tecnologías Físicas, Universitat Politècnica de València, EPS Gandia, C/Paranimf, 1, Grao de Gandia, \\ 46730 Valencia, Spain; roderey@fis.upv.es (R.d.R.); jesalba@fis.upv.es (J.A.); lauberca@upvnet.upv.es (L.B.) \\ * Correspondence: juarodve@upv.es
}

Received: 31 January 2019; Accepted: 1 March 2019; Published: 7 March 2019

\begin{abstract}
In order to assess the airborne sound insulation of a new material or building solution, access to standardized laboratories, large and expensive facilities, and a sample area of at least $10 \mathrm{~m}^{2}$ are required. At the research and development stages of new sustainable acoustic materials for construction, it is not easy to make large sample areas available. Moreover, the financial investment in acoustic testing of materials during the research stage in standardized laboratories is excessive. In this work, the assessment of the airborne sound insulation of multi-layer partitions designed with new sustainable materials is presented. The assessed solutions are formed by green composite fiber boards as lightweight elements and a new material designed from sheep wool as absorbent material. The results of these $100 \%$ recyclable solutions are compared with lightweight element based solutions, which are commonly used for acoustic insulation. Characterization of those new sustainable solutions for building is leveraged in a reduced sized transmission chamber. The design, construction, and validation of this kind of laboratory are provided. This laboratory enables the assessment of the airborne sound insulation of a material in its research stage.
\end{abstract}

Keywords: sound insulation in buildings; air-borne sound transmission; innovative acoustic material; sustainable acoustics; acoustic characterization; green composites; sheep wool

\section{Introduction}

Traditionally, the absorbent material employed in buildings as acoustic solutions contained toxic mineral wools or materials that were difficult to recycle. Starting in the late 1990s and the beginning of the 21st century, we gradually began to see the benefits of using natural fibers as an alternative to synthetic ones; they provided high thermal and acoustic properties with a low impact on the environment and human health [1]. Over the years, researchers have conducted numerous studies to evaluate the acoustic and thermal properties of a multitude of natural fibers [2-9] and recycled materials [10-15]. They have made simulation models with these new materials [16-19] and have even conducted studies on how plants can improve acoustics both indoors and outdoors [20-22]. This trend in the search of sustainable, recycled, and recyclable materials, which are friendly both to the environmental and to human health, is gaining increasingly greater force [23]. Currently, the HORIZON2020 program is up and running [24] and is the most ambitious research and innovation program set up by the European Union (EU). This program funds research and innovation projects in various subject areas in the European context and, in particular, its Action 5 poses different plans to be put into action. One of them refers to "enabling the transition towards a green economy and society through eco-innovation" by reinforcing innovative sustainable products, among others. Therefore, included within this new group of products may be sustainable materials produced with waste products from other manufacturing processes, natural fibers, or recycled materials that can be converted into acoustic materials. To be able to introduce new eco-acoustic materials in construction, 
civil engineering, industry, and transport, they must meet some requirements. For example, in some EU member countries, there is legislation such as The Basic Document regarding Noise Protection of the CTE (Código Técnico de la Edificación-Spanish Technical Building Code-) [25], which requires that building products meet certain requirements. The specifications of a construction project must contain the acoustic characteristics of the products and construction elements employed in the project. These acoustic characteristics are obtained through laboratory testing.

One of these acoustic characteristics of a building solution is the sound reduction index $(\mathrm{R}(\mathrm{dB}))$ which has to be measured in a standardized laboratory. In order to obtain this parameter, acoustic transmission chambers are needed. Normalized conditions that these chambers have to comply with are described in the International Organization for Standardization (ISO) 10140-5:2010 standard [26]. These chambers are composed of two rooms-a source room and a receiving room-and the test sample is placed between them. According to the ISO 10140-1:2010 specifications (currently replaced by the ISO 10140-1:2016 standard [27]), in order to evaluate the airborne sound insulation, at least $10 \mathrm{~m}^{2}$ of material is required.

At a research level, the high cost of this type of laboratory and the large amount of material necessary for its evaluation represents a major handicap. During the development of new products, high quantities of material are not usually available, and it is difficult to channel an important part of the budget to standard laboratory tests until the final product has been developed.

There are methods for the evaluation of acoustic parameters in normal incidence, and the amount of necessary material for the tests when using these methods is very small. For example, the sound transmission through a material in normal incidence can be determined with samples of a few centimeters of diameter. This sound transmission gives information about airborne noise. The test method for the measurement of this parameter in normal incidence by using an impedance tube is described in the standard ASTM E2611-17 [28] and is based on the definition of a transfer matrix. By using this method, the handicap of not having enough material available for standardized tests is avoided, but only information about normal incidence can be obtained. The method described in [28] does not consider the material behavior as a function of the sound incidence angle.

With the reduced sized transmission chamber used to characterize the presented sustainable solutions, the effect of the diffuse field can be analyzed with sample sizes below $1 \mathrm{~m}^{2}$. By using the reduced sized transmission chamber, production costs of the samples are reduced, and improvements can be considered during its development.

All of this together with the recent importance of acoustic comfort [29-33] has led researchers to search for tools that allow them to quickly, easily, and economically assess airborne sound insulation for the validation of new building solutions in the research and development stages.

Therefore, the main target of this work is to validate the proposed sustainable solutions as airborne sound insulation solutions for multi-layer lightweight partitions. The proposed solutions, which are presented in the next sections, are designed with new sustainable materials in respect of the environment.

In order to validate the solutions elaborated from materials still in development stages, a reduced sized transmission chamber was used.

A reduced sized transmission chamber reproduces the geometry of standard transmission chambers to scale. Other authors have used reduced sized chambers for the acoustic characterization of materials or building solutions [34-38]. The reduced sized transmission chamber presented in this work was designed following the same line of work that followed the first authors who developed this kind of enclosure [34]. In their work, Godinho et al. describe the design of a small-sized acoustic chamber with a volume of $2.73 \mathrm{~m}^{3}$. The volume of the reduced sized transmission chamber presented in this work was smaller, as is described later in this document (Table 1). In [34], the authors study the behavior of a small-sized parallelepiped reverberant chamber in the estimation of the impact sound reduction provided by lightweight floor coverings. 
Table 1. Data from the design of the chamber and the final dimensions.

\begin{tabular}{|c|c|c|c|}
\hline & $\begin{array}{l}\text { Dimensions According to International } \\
\text { Organization for Standardization (ISO) Standard }\end{array}$ & $\begin{array}{l}\text { Dimensions Reduced } \\
\text { by a Factor of 1:5 }\end{array}$ & Final Dimensions \\
\hline Source Room Volume $\left(\mathrm{m}^{3}\right)$ & 60.00 & 0.48 & 0.44 \\
\hline Receiving Room Volume $\left(\mathrm{m}^{3}\right)$ & 50.00 & 0.40 & 0.38 \\
\hline Minimum length of a room edge (m) & 2.30 & 0.46 & 0.55 \\
\hline
\end{tabular}

\section{Construction of the Reduced Sized Transmission Chamber}

\subsection{Design and Construction}

The reduced sized transmission chamber, which was used to characterize the sustainable solutions, was designed and built in 2011 and was a prototype for the European Project LIFE NOISEFREETEX (LIFE09 ENV/IS/461) [39,40]. The design was based on the specifications of the standard ISO 140-1:1997 [41] (standard currently annulled and replaced by ISO 10140-5:2010 [26]), which indicates the basic conditions that a laboratory of this type must have. The reduced sized transmission chamber was designed taking into account acoustic insulation and spatial distribution of the diffusivity. The geometric relationship proposed for the rooms was evaluated through the resonance frequencies themselves using the finite element method (FEM), and the design of energy interaction was also evaluated using a statistical energy analysis (SEA) model [42]. The diffuse field condition and specifications relating to the reverberation time in the design phase described in $[42,43]$ were considered. Table 1 shows the comparison between the dimensions required by the standards and these dimensions reduced by a factor of 1:5 for the construction of the reduced sized chamber. The final dimensions of the reduced sized transmission chamber deviated slightly from the 1:5 factor reduced dimensions. The deviations were due to the handmade construction of the chamber.

With regards to the geometry of the chamber, the basis for defining it was the theory from the modes themselves and Bolt's criterion [44], looking for a modal distribution that would be as uniform as possible inside the rooms it was comprised of (a source room and a receiving room). Together with the geometry, the acoustic insulation of the walls that made up the chamber also played an important role. The insulation had to be sufficient enough to prevent any outside noise from masking the tests measures.

The materials used for the construction of the walls that made up the reduced sized transmission chamber were as follows (from indoor to outdoor): $6 \mathrm{~mm}$ thick composite (Alucobond ${ }^{\circledR}$ ), $15 \mathrm{~mm}$ thick plasterboard, $10 \mathrm{~mm}$ thick high density viscoelastic material, $12.5 \mathrm{~mm}$ thick plasterboard, $90 \mathrm{~mm}$ width aluminum profiles (thermo-fused fibers), $12.5 \mathrm{~mm}$ thick plasterboard, $10 \mathrm{~mm}$ thick high density viscoelastic material, and $15 \mathrm{~mm}$ thick plasterboard. This sandwich solution was chosen because it provided a robust structure that allowed the walls to be tilted where necessary according to the geometrical design; it also provided a high airborne sound insulation. Figure 1 shows the completed reduced sized transmission chamber. 


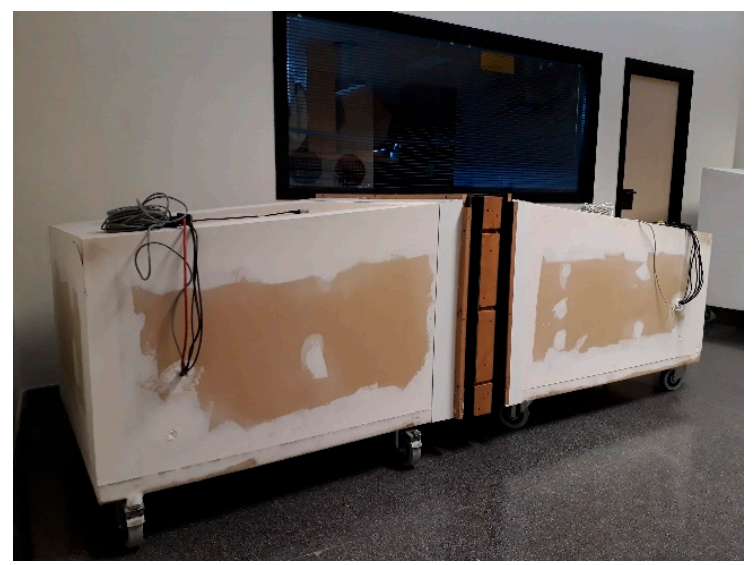

(a)

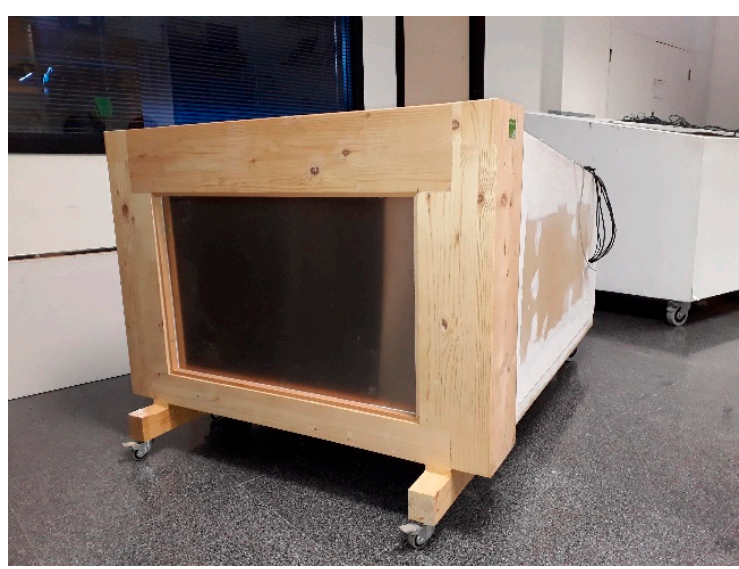

(b)

Figure 1. Completed reduced sized transmission chamber: (a) the two rooms with the sample holder in between; (b) view of the sample holder.

\subsection{Initial State and Preparation}

Initial measurements of airborne sound insulation were taken, with certain limitations and adjustments, by adapting the specifications of the standard ISO 10140-4:2010-Measurement procedures and requirements [45]. The following steps outline the procedure for testing the airborne sound insulation of a material or building solution.

1. Generate white or pink noise in the source room by means of a sound source placed in two positions in the room.

2. Measure the sound pressure level both in the source room and in the receiving room in five microphone positions for each sound source position.

3. Measure the background noise (when the sound source is not emitting noise) in the receiving room in five microphone positions.

4. Measure the reverberation time in the receiving room by adapting the specifications of the ISO 3382-2:2008 [46] standard.

The chosen positions of the sound source and the microphone had to have a minimum distance between each other, between them and the walls, between the floor and/or the ceiling of the chamber, and even between the microphone and the sound source [45]. The dimensions of the reduced sized transmission chamber (volumes less than $0.5 \mathrm{~m}^{3}$ ) were adjusted in relation to the scale factor of 1:5 applied in the design of the small laboratory. Table 2 indicates the minimum distances that were considered in order to place the sound source and microphone in their positions during the tests.

Table 2. Minimum separation distances to comply with in the reduced sized transmission chamber.

\begin{tabular}{cc}
\hline According to the Standard ISO 10140-4:2010 & According to the Size of the Small Transmission Chamber \\
\hline 0.7 $\mathrm{m}$ between microphone positions & $0.14 \mathrm{~m}$ between microphone positions \\
$0.7 \mathrm{~m}$ between microphone position and walls & $0.14 \mathrm{~m}$ between microphone position and walls \\
$0.7 \mathrm{~m}$ between microphone position and diffusers & $0.14 \mathrm{~m}$ between microphone position and diffusers \\
$1.0 \mathrm{~m}$ between microphone position and the wall under test & $0.2 \mathrm{~m}$ between microphone position and the wall under test \\
$1.0 \mathrm{~m}$ between any microphone position and the source & $0.2 \mathrm{~m}$ between any microphone position and the source \\
\hline
\end{tabular}

\subsection{Acoustic Evaluation}

After the design and construction of the reduced sized transmission chamber and setting up the measurement system, the acoustic evaluation was carried out. Four essential parameters define the acoustic performance of the reduced sized transmission chamber: reverberation time, sound field 
diffusivity, cutoff frequency, and flanking transmission. The evaluation of those acoustic parameters is presented in the next sections, except flanking transmission, which can be consulted in detail in [47].

\subsubsection{Reverberation Time}

The ISO 10140-5:2010 standard [26] establishes that the reverberation time (TR(s)) inside the transmission chamber must be over $1 \mathrm{~s}$ but less than a value related to its volume (V), according to (1). This condition, adapted to the scale of the volume of the transmission chamber, set the limits of the reverberation time to between 0.20 and $0.39 \mathrm{~s}$ for the receiving room and between 0.20 and $0.45 \mathrm{~s}$ for the source room.

$$
1 \leq \mathrm{TR}(\mathrm{s}) \leq 2 \cdot\left(\frac{\mathrm{V}}{50}\right)^{\frac{2}{3}}
$$

The reverberation time measured in each room (TR(s) initial) is presented in Figure 2. Below $630 \mathrm{~Hz}$ in both rooms meant the reverberation time was outside the set limits. This supposed a limit with respect to the regulatory specifications, thus the results obtained below $630 \mathrm{~Hz}$ were treated with caution. As is detailed in the following sections of this text, this limitation was related to the cutoff frequency of the chamber.

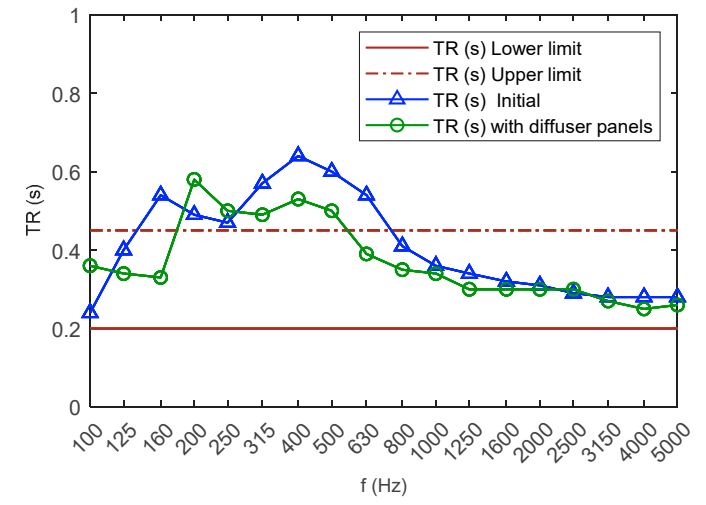

(a)

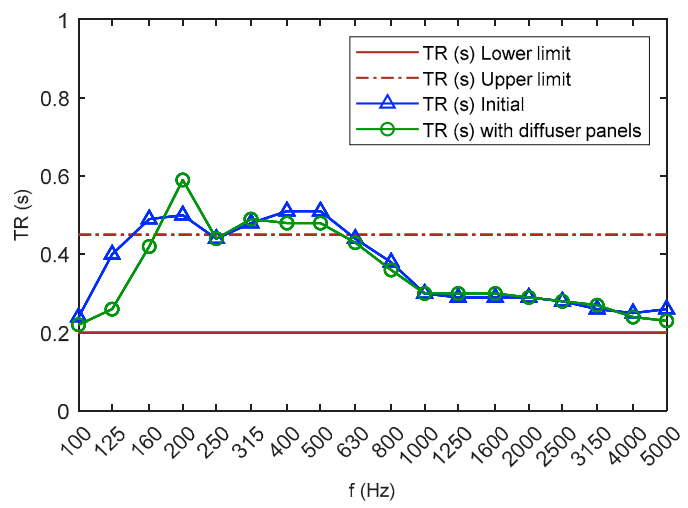

(b)

Figure 2. Reverberation time (TR) for source and receiving rooms: (a) source room; (b) receiving room.

\subsubsection{Sound Field Diffusivity}

The sound field inside the source and receiving rooms had to be as diffused as possible. The ISO 10140-5:2010 standard [26] specifies that large variations in the sound pressure level in a room indicate the presence of strong dominant waves. In this case, diffusing elements needed to be put in place in order to minimize these variations between the measurement positions. Sound pressure level (SPL) was evaluated in the ten fixed microphone positions both in the source and in the receiving rooms, and a high level of deviation was detected, particularly at low frequencies (Figure 3).

In order to reduce the deviation of the sound pressure level between different measurement points, diffuser panels were installed based on the specifications of Annex A of the ISO 354:2003 standard [48]. The diffusers were constructed with $5 \mathrm{~mm}$ thick plywood with a dimensions range between $50 \mathrm{~cm}^{2}$ and $500 \mathrm{~cm}^{2}$ covering a total area (double-sided) of $0.27 \mathrm{~m}^{2}$ in the source and $0.25 \mathrm{~m}^{2}$ in the receiver. Four panels were installed in the source room and five panels in the receiving room, all of them distributed randomly as the Annex A of the ISO 354:2003 standard [48] states.

The sound pressure level in the source and receiving rooms was measured, and the effectiveness of the installation of the diffuser panels was analyzed. Figure 3 shows the comparative sound pressure level deviation before and after the installation of the diffuser panels. As shown in the measurements results, the deviation between the measurement points decreased substantially after the installation of the diffuser panels, especially at low frequencies. 
With the installation of the diffusers, the uniformity of the sound field was considerably improved, and therefore so were the repeatability and reliability of the results. In addition, the introduction of diffuser panels also influenced the reverberation time, especially in the source room. The frequency based results presented in Figure 2 correspond to 1/3-octave bands measurements according to the ISO 10140-4:2010 standard [45].

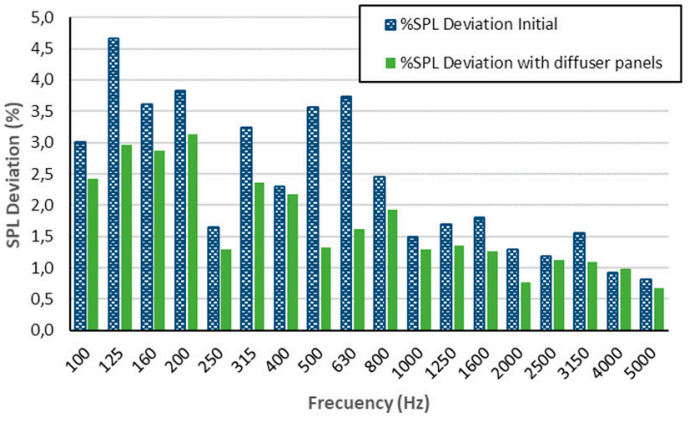

(a)

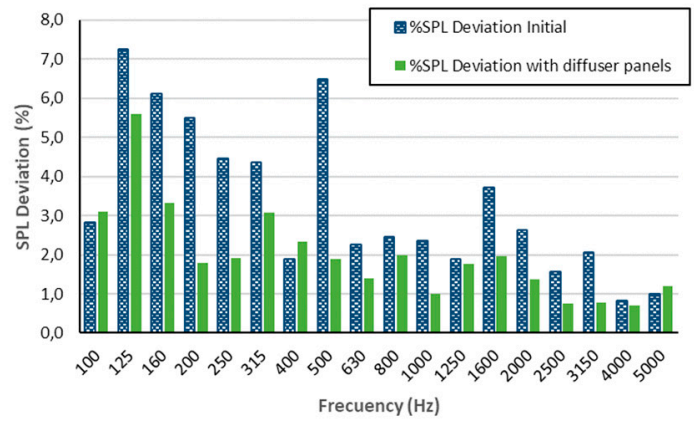

(b)

Figure 3. Sound pressure level (SPL) deviation for source and receiving rooms: (a) source room; (b) receiving room.

\subsubsection{Cutoff Frequency}

In a room at a specific frequency, the modal density is high enough for the modes themselves not to involve a variation of the frequency response of the room. That frequency marks the upper limit of the low frequency area of the room and is called the critical or cutoff frequency.

In 1954, Schroeder [49] found this critical frequency based on 10 modes in each 1/3-octave; however, after years of experiments and measurements taken, a more adequate equation [50] was found for the cutoff frequency, or the Schroeder frequency (2):

$$
F_{c}=1849 \cdot \sqrt{\frac{T_{60}}{V}}
$$

In 2011, Magne Skålevik [51] made a revision to the Schroeder frequency, proposing a new equation that consisted of multiplying the Schroeder frequency by a factor of 0.45 .

This revision of Schoreder's cutoff frequency Equation (2) was applied to each 1/3-octave band, and the average value was calculated. The original cutoff frequency of the room was established at $1485 \mathrm{~Hz}$. Through the revision of the Schroeder frequency by Skålevik, the cutoff frequency of the enclosed environment was set to $668 \mathrm{~Hz}$ rounded down to one third of an octave at $630 \mathrm{~Hz}$. Therefore, below $630 \mathrm{~Hz}$, it cannot be ensured that the modes themselves do not dominate the room, consequently having a strong influence in the results. Thus, the results obtained in this reduced sized transmission chamber below $630 \mathrm{~Hz}$ were evaluated with care.

The standing waves phenomena, especially small modal density, suppose a limitation in the accuracy of measurements in lower frequency spectra depending on the size of the room. There are plenty of publications about that, even publications describing how to determine sound transmission loss by neglecting the impact of sound transmission chambers. Some recent examples are [52-55].

\section{Materials: Green Composites and Sheep Wool}

\subsection{Green Composites}

Green composites used for the manufacturing of the acoustic solutions presented in this work were part of the results obtained in the BIAFIREMAT national project, "Development of new eco-materials and sustainable constructive solutions, based in the use of residues and renewable raw materials", 
funded by the Spanish Ministry of Economy and Competitiveness and co-financed with funds from the European Regional Development Fund (ERDF) within the 2013 National RDI Programme Aimed at Society's Challenges. In order to meet the objectives of this project, the search for new sustainable materials that can be used in building was needed. Sustainable materials elaborated from industry wastes, natural fibers, or recycled products are some examples of needed materials. Details of the composition and the elaboration of the assessed boards are described in [56]. In that work, the main advantages of the materials against typical building materials elaborated from synthetic fibers are shown; they are elaborated from natural fibers, which are renewable, less abrasive, and have a more optimal lifecycle.

In [57], results of the acoustic characterization of ten composite boards are shown. The difference between the boards relies on the type of base resin used for their manufacture, biodegradable resin (SUPER SAP ${ }^{\circledR}$ CLR Epoxy) or polyester resin (NORSODYNE H 13328 A). From the set of ten composites, four of them were chosen for manufacturing the solutions proposed in this work-the ones elaborated with jute and textile waste fibers plus biodegradable and polyester resins. Some of their characteristics are shown in Table 3.

Table 3. Characteristics of green composite boards.

\begin{tabular}{|c|c|c|c|}
\hline Board Composition & Fiber Volume (\%) & Board Thickness $\left(10^{-3} \mathrm{~m}\right)$ & Board Density $\left(10^{3} \mathrm{~kg} / \mathrm{m}^{3}\right)$ \\
\hline Textile waste fibers and biodegradable resin & 0.73 & 4.9 & 1.07 \\
\hline Textile waste fibers and polyester resin & 0.71 & 4.6 & 1.23 \\
\hline Jute fibers and biodegradable resin & 0.70 & 5.1 & 1.08 \\
\hline Jute fibers and polyester resin & 0.60 & 4.7 & 1.12 \\
\hline
\end{tabular}

In Figure 4, jute and textile waste fiber blankets are shown, as well as the elaborated boards after being treated with biodegradable resin. Please note that boards made with either of the two types of the resin presented in this work look almost the same.

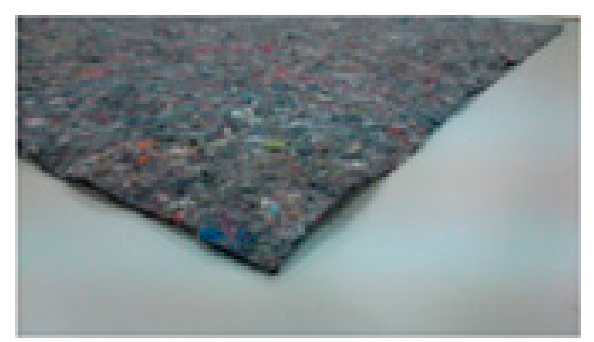

(a)

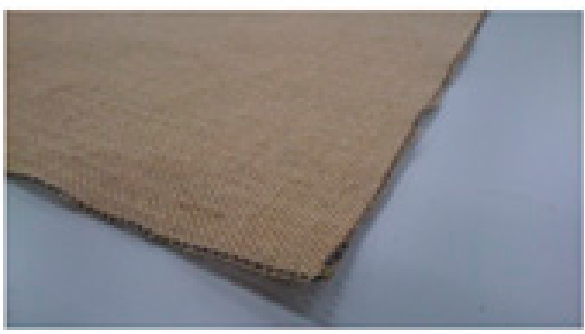

(c)

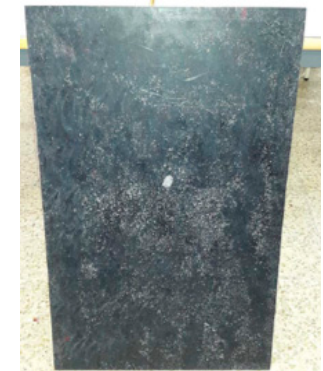

(b)

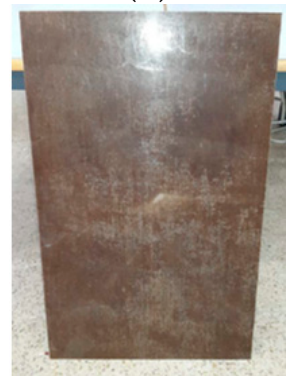

(d)

Figure 4. (a) Textile waste blanket; (b) textile waste treated with biodegradable resin board; (c) jute fiber blanket; (d) jute fiber treated with biodegradable resin board.

\subsection{Sheep Whool}

The acoustic absorbent materials elaborated from sheep wool that were used to manufacture the acoustic solutions presented in this work were part of the result of 
the European project ECO-INNOVATION-WOOL4BUILD ECO/13/630249-WOOL4BUILD "IMPROVED ISOLATION MATERIAL FOR ECO-BUILDING BASED ON NATURAL WOOL (ECO-INNOVATION-WOOL4BUILD ECO/13/630249 WOOL4BUILD [58]. The main objective of the project was to develop a sustainable product for building insulation that provided good performance-both in acoustic and thermal insulation-and that was based on sheep hair and wool residues produced in the tannery industry. In $[59,60]$, the objective of the project was developed in detail, and data on the diameter of the fibers and comparison with other fibers already consolidated as acoustic absorbents-like polyester fibers (PET), recycled foam, and mineral wool-were presented. In those works, some typical acoustic characterization parameters such as airflow resistivity, normal-incidence sound absorption coefficient, and random incidence sound absorption coefficient were also presented. The results presented in those works were from sheep wool samples of different composition, thickness, and density. The samples presented in this work are the ones denominated S5 [59] and Premium [60]. Some of their characteristics are shown in Table 4.

Table 4. Characteristics of some of the evaluated sheep wools in the WOOL4BUILD project.

\begin{tabular}{|c|c|c|c|c|c|}
\hline & \multicolumn{3}{|c|}{ Composition (\%) } & \multirow{2}{*}{ Density $\left(\mathrm{kg} / \mathrm{m}^{2}\right)$} & \multirow{2}{*}{ Thickness $\left(10^{-3} \mathrm{~m}\right)$} \\
\hline & PET BI-CO & 1st Quality Wool & 2nd Quality Wool & & \\
\hline S5 & 20 & 40 & 40 & 30 & 60 \\
\hline Premium & 15 & 40 & 45 & 30 & 50 \\
\hline
\end{tabular}

\section{Results}

\subsection{Acoustic Validation of the Reduced Sized Transmission Chamber}

In order to validate the reduced sized transmission chamber, airborne sound insulation tests were carried out for certain building solutions. This type of test is an indispensable tool in the research and development of new products or building solutions used in the building industry.

The test procedure for airborne sound insulation measurement in the reduced sized transmission chamber followed the specifications of the ISO 10140-2:2010 standard [61] with certain adaptations and limitations due to its reduced size. The ISO 10140-2:2010 standard references the ISO-10140-4:2010 standard, where procedures for the measurement of sound pressure level and reverberation time are established. These necessary adaptations for the reduced sized transmission chamber are presented Table 2.

In order to validate the results of airborne sound insulation obtained for the tests carried out in the reduced sized transmission chamber, they were compared with results obtained in standard transmission chambers and the theoretical results obtained through simulation with Aisla 3 prediction software [62]. This simulation software is based on the predictive models of acoustic insulation described by Ookura \& Saito and Chen \& Jan $[63,64]$ based on impedance coupling with known mechanical data of the materials (elastic module, loss factor, thickness, and density).

Figure 5 shows the sound reduction index (R) obtained by the different methods described above. The presented results belong to one of the test configurations used to validate the reduced sized transmission chamber, which consisted of a single $13 \mathrm{~mm}$ thick plasterboard. 


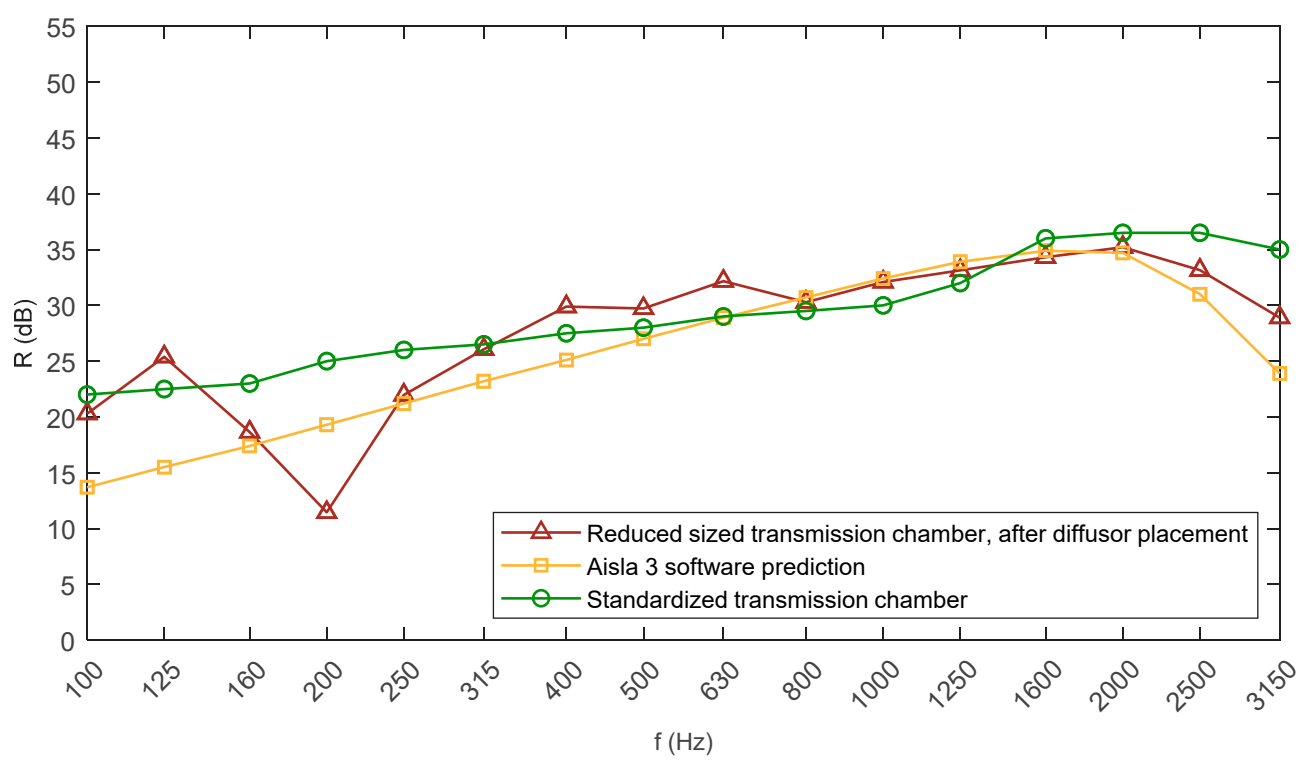

Figure 5. Comparison of the results obtained for a single $13 \mathrm{~mm}$ thick plasterboard.

Figure 5 displays the degree of coincidence between the results obtained by the different methods described above from the chamber's cutoff frequency $(630 \mathrm{~Hz})$ upwards. These results validate the reduced sized transmission chamber as a small testing laboratory for this type of building solutions.

\subsection{Acoustic Characterization of the Proposed Sustainable Solutions}

Once the reduced sized transmission chamber was validated, it was possible to perform the initial tests of materials under development in a quick and economical way, which supposed an advantage during the analysis of the proposed sustainable solutions. First, the acoustic tests of the lightweight elements and the absorbent materials that conformed to the proposed sustainable solutions were carried out. Once the results were analyzed, some possible combinations of the different proposed materials were analyzed as a whole in order to check acoustic behavior as a sustainable solution for multi-layer lightweight partition.

\subsubsection{Acoustic Characterization of the Green Composite Boards}

The boards detailed in Table 3 were characterized as sound-proof layers with properties of lightweight partition for airborne sound insulation. All the tests were carried out in the reduced sized transmission chamber described earlier in this text.

Sound reduction index values $(\mathrm{R}(\mathrm{dB})$ ) were obtained as a function of frequency for the textile waste and jute fibers with biodegradable resin boards that are shown in Figure 4. All of these tests were performed in the reduced sized transmission chamber. Values starting at $100 \mathrm{~Hz}$ are presented in Figure 6. As detailed in Section 2.3, only values from $630 \mathrm{~Hz}$ upwards were considered reliable.

Figure 6 shows quite similar tendencies between the sound reduction index values as functions of frequency of the four green composite boards detailed in Table 3. The similar tendencies between the green composite boards and the plasterboard can also be seen. The four green composite boards presented sound reduction index values that were always below the values of the plasterboard, but it is worth noting that the green composite boards were approximately $5 \mathrm{~mm}$ thick, and the plasterboard was $13 \mathrm{~mm}$ thick. 


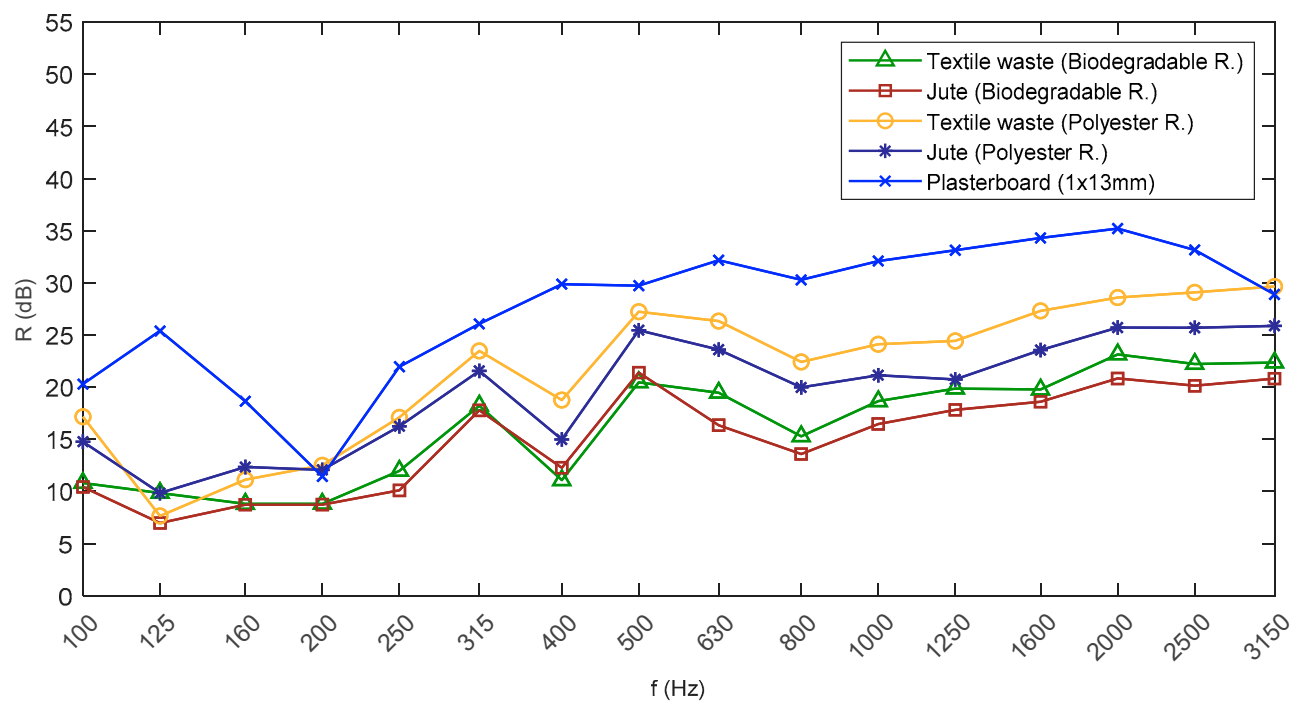

Figure 6. Sound reduction index $(\mathrm{R}(\mathrm{dB}))$ measured in reduced sized transmission chamber for green composite and plaster boards.

\subsubsection{Acoustic Characterization of the Sheep Wool Samples}

The sheep wool samples described in Table 4 were characterized as sound absorbers. In order to carry out the acoustic characterization, three different tests were conducted-airflow resistance by Ingard \& Dear's method [65], normal incidence absorption coefficient following the guidelines of the ISO 10534-2:1998 standard [66], and sound absorption in a reverberation room following the guidelines of the ISO 354:2003 standard [48]. Full details of each of these tests are described in [59] for S5 and in [60] for Premium.

Values of airflow resistance are presented Table 5 and normal incidence absorption coefficient and random incidence absorption coefficient are presented in Figures 7 and 8, respectively.

Table 5. Airflow resistance of sheep wool samples.

\begin{tabular}{cc}
\hline & Airflow Resistance $($ rayls $/ \mathbf{m}) \times \mathbf{1 0 0 0}$ \\
\hline S5 & 7.2 \\
Premium & 8.3 \\
\hline
\end{tabular}

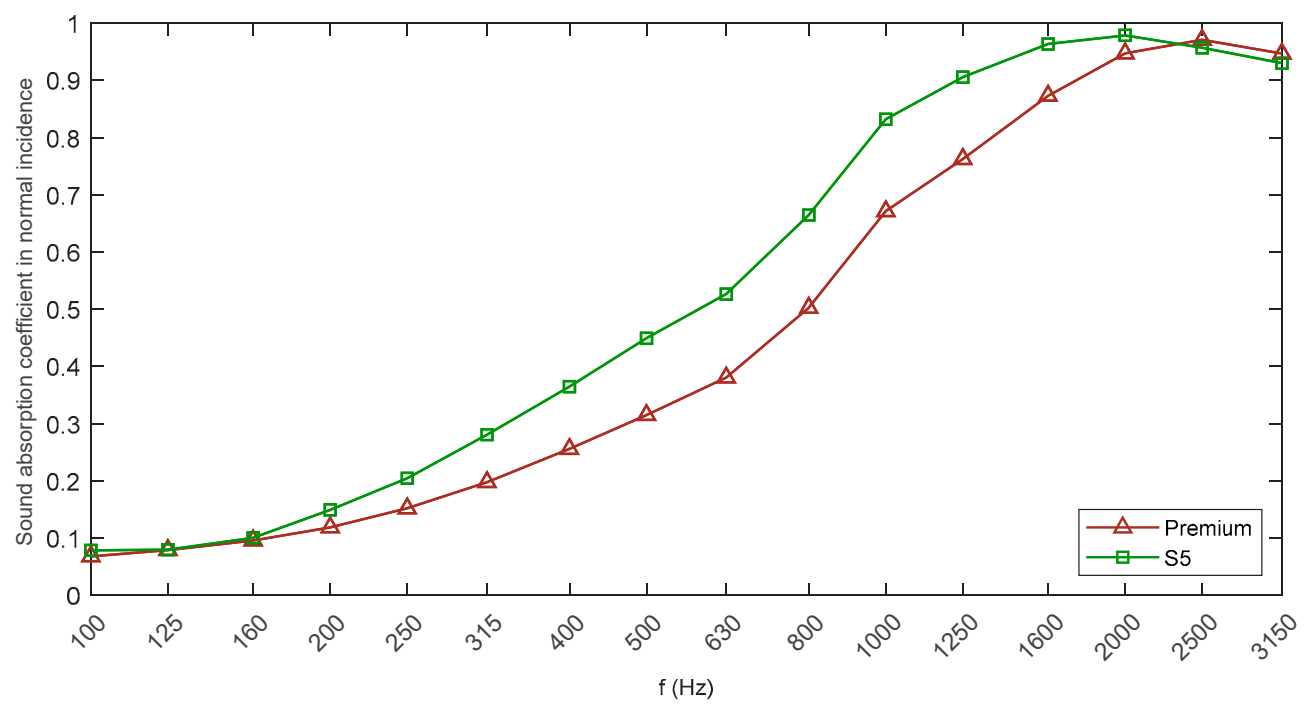

Figure 7. Sound absorption coefficient in normal incidence of Premium and S5 sheep wools. 


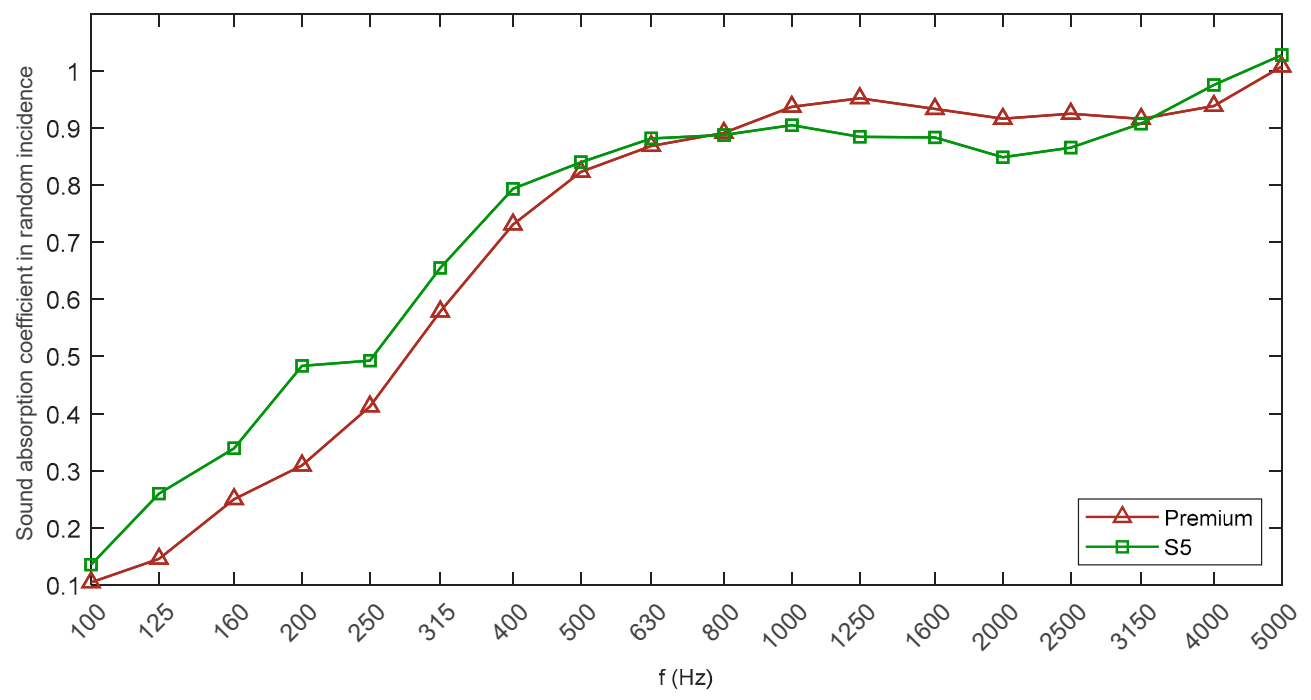

Figure 8. Sound absorption coefficient in random incidence of Premium and S5 sheep wools.

As can be observed in Figures 7 and 8, both in normal incidence and random incidence, Premium and S5 samples presented both values and tendencies for the sound absorption coefficient as functions of frequency typical of absorbent materials.

\subsubsection{Acoustic Characterization of the Proposed Sustainable Solutions}

Once the different individual elements were acoustically characterized, four combinations of them were analyzed as possible solutions for multi-layer lightweight structures:

1. Textile waste fibers and biodegradable resin board + S5 Sheep Wool + Jute fibers and biodegradable resin board (70 $\mathrm{mm}$ thick).

2. Textile waste fibers and biodegradable resin board + Premium Sheep Wool + Jute fibers and biodegradable resin board (60 $\mathrm{mm}$ thick).

3. Textile waste fibers and polyester resin board + S5 Sheep Wool + Jute fibers and biodegradable resin board (70 $\mathrm{mm}$ thick).

4. Textile waste fibers and polyester resin board + Premium Sheep Wool + Jute fibers and biodegradable resin board (60 $\mathrm{mm}$ thick).

Results of sound reduction index as a function of frequency measured in the reduced sized acoustic chamber are presented in Figure 9. In addition to the four proposed sustainable solutions, results of two alternative solutions based on a combination of plasterboard as a lightweight element and sheep wool as a sound absorber are also included.

As can be observed in Figure 9, the configuration that presented lower airborne sound insulation was configuration 1 (Textile waste fibers and biodegradable resin board + S5 Sheep Wool + Jute fibers and biodegradable resin board), followed by configuration 4 (Textile waste fibers and polyester resin board + Premium Sheep Wool + Jute fibers and biodegradable resin board), followed by configuration 3 (Textile waste fibers and polyester resin board + S5 Sheep Wool + Jute fibers and biodegradable resin board), and the one that presented the higher insulation level was configuration 2 (Textile waste fibers and biodegradable resin board + Premium Sheep Wool + Jute fibers and biodegradable resin board).

The obtained results also indicate that all the green composite boards represented in Figure 6 could be used as airborne sound insulation solutions. Boards that individually presented higher airborne sound insulation when combined with absorbent material in order to form a multi-layer solution presented lower airborne sound insulation than solutions formed by other boards, which individually presented lower airborne sound insulation and the same absorbent material. Thus, in a 
multi-layer partition, the right materials choice does not exclusively depend on the acoustic insulation of each individual element; it must be analyzed as a whole.

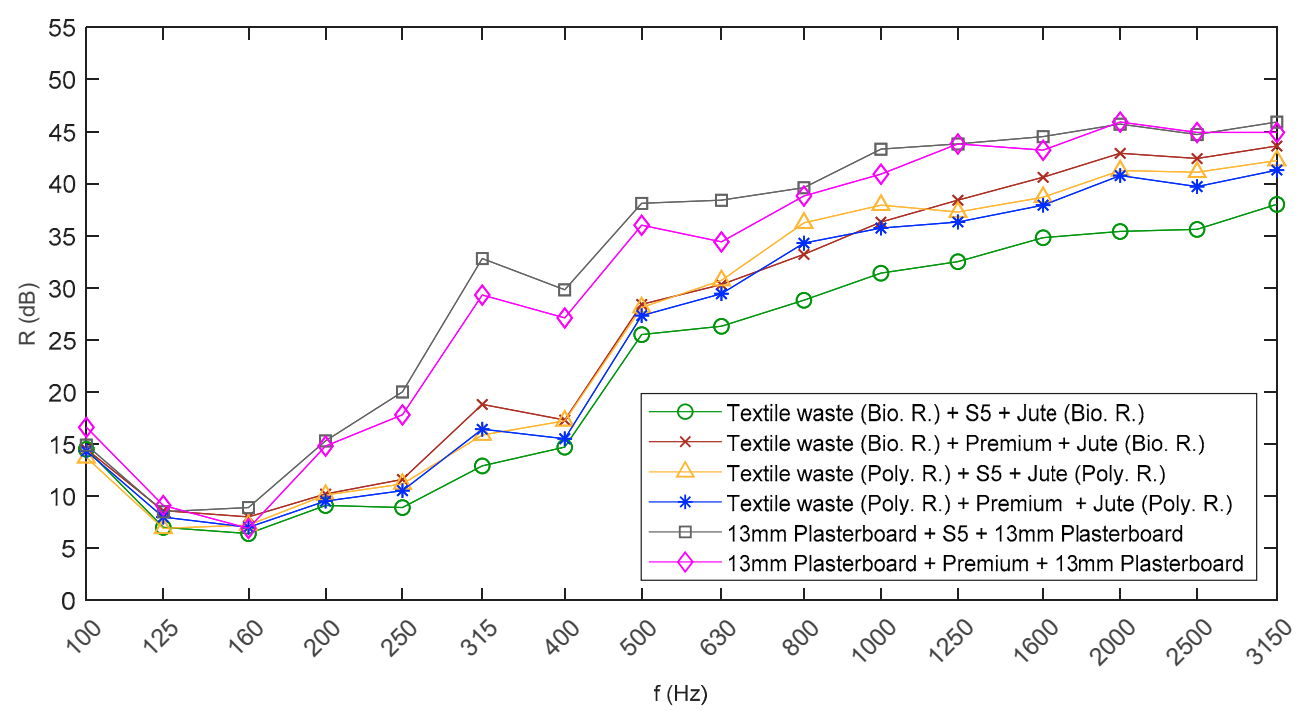

Figure 9. Sound reduction index of the proposed solutions measured in the reduced sized transmission chamber.

\section{Conclusions}

In this paper, airborne sound insulation of some proposed sustainable solutions was studied. These lightweight solutions were designed from materials in development phases. In order to evaluate these sustainable configurations, a reduced sized transmission chamber was used-a chamber that presented some measurement limitations and was used to assess lightweight partitions. Due to its reduced size, only values from $630 \mathrm{~Hz}$ upwards were considered valid. This type of chamber was used in order to reduce the manufacturing cost of the samples (samples of less than $1 \mathrm{~m}^{2}$ were needed compared to the $10 \mathrm{~m}^{2}$ needed for the normalized chamber). It is an alternative that allows comparison of acoustic solutions and divulges more information than other types of tests based on Kundt's tube.

In order to justify the acoustic insulation values obtained in the reduced sized transmission chamber and their validity range, several acoustic parameters were presented. The design and construction of the reduced sized transmission chamber, the measurement procedure, and its acoustic evaluation were described. In the acoustic evaluation, the limitations derived from the reverberation time, the sound field diffusivity, and the cutoff frequency were presented. The cutoff frequency was considered the most limiting factor, and it was set at $630 \mathrm{~Hz}$. The validity range of the measures presented in this work was conditioned to that value. Although the work included results for all the test ranges of a normalized acoustic chamber (starting at $100 \mathrm{~Hz}$ ), only results from $630 \mathrm{~Hz}$ upwards were reliable, and the assessed solutions were compared parting from that frequency.

In order to justify the validity of the results, values of airborne sound insulation from a set of known lightweight configurations obtained in this chamber, such as plasterboard, were compared with values obtained in standardized chambers and with theoretical values obtained from predictive models. The results are an example of the reduced sized transmission chamber validation for comparative tests of lightweight materials.

Two types of fibers were used to build green composite boards-jute fibers and textile waste fibers. For each of them, $5 \mathrm{~mm}$ thick boards were made using two different resin treatments, one with biodegradable resin and the other with polyester resin.

The results of airborne sound insulation tests for all these boards were presented. As can be observed in Figure 6, the board composed by textile waste fibers with polyester resin was the one that produced better airborne sound insulation results. Compared to the solution made up with $13 \mathrm{~mm}$ 
plasterboard (also presented in Figure 6), the obtained results for the green composite boards show a good behavior if the thickness difference is taken into account.

Tests for lightweight solutions composed by combinations of the assessed green composite boards and acoustic sheep wool were also carried out. Those wools were also described in this work and are currently being commercialized. In Figure 9, the results for airborne sound insulation were presented. In general, the different combinations had similar behaviors and were suitable for airborne sound insulation solutions except for the solution composed by textile waste resin board with S5 wool and jute board, which presented results with an average of $5 \mathrm{~dB}$ less than the other solutions. These results were also compared with similar configurations obtained by replacing the green composite board with plasterboards. In Figure 9, the results of two solutions composed of $13 \mathrm{~mm}$ plasterboard combined with the two types of analyzed sheep wool (S5 and Premium) were also presented. These solutions also produced good results, thus sheep wool can be considered an alternative for lightweight solutions with plasterboard.

The results obtained for the proposed sustainable solutions indicate that the proposed solutions could be used as sustainable solutions for airborne sound insulation. In the case of the solutions composed of plasterboard and sheep wool, they can already be used as an alternative for lightweight solutions. However, in the case of the green composite boards, there are still other aspects pending analysis, such as fire resistance and mechanical durability in time.

Author Contributions: R.d.R., J.A. and L.B. conceived and designed the experiments; R.d.R. performed the experiments; R.d.R. and J.C.R. analyzed the data; J.A. and J.C.R. participated in the analysis of the state-of-the-art and in the design of some experiments, as well as in the drafting of the manuscript.

Funding: This work was financially supported by the project BIA2013-41537-R (BIAEFIREMAT “Development of new eco-materials and sustainable constructive solutions based on the use of waste and renewable raw materials"), funded by the Spanish Ministry of Economy and Competitiveness and co-financed with funds from the European Regional Development Fund (ERDF), within the 2013 National RDI Programme Aimed at Society's Challenges.

Conflicts of Interest: The authors declare no conflict of interest.

\section{References}

1. Berardi, U.; Iannace, G. Predicting the sound absorption of natural materials: Best-fit inverse laws for the acoustic impedance and the propagation constant. Appl. Acoust. 2017, 115, 131-138. [CrossRef]

2. Asdrubali, F.; Bianchi, F.; Cotana, F.; D'Alessandro, F.; Pertosa, M.; Pisello, A.L.; Schiavoni, S. Experimental thermo-acoustic characterization of innovative common reed bio-based panels for building envelope. Build. Environ. 2016, 102, 217-229. [CrossRef]

3. Berardi, U.; Iannace, G. Acoustic characterization of natural fibers for sound absorption applications. Build. Environ. 2015, 94, 840-852. [CrossRef]

4. Kymäläinen, H.-R.; Sjöberg, A.-M. Flax and hemp fibres as raw materials for thermal insulations. Build. Environ. 2008, 43, 1261-1269. [CrossRef]

5. Or, K.H.; Putra, A.; Selamat, M.Z. Oil palm empty fruit bunch fibres as sustainable acoustic absorber. Appl. Acoust. 2017, 119, 9-16. [CrossRef]

6. Glé, P.; Gourdon, E.; Arnaud, L. Acoustical properties of materials made of vegetable particles with several scales of porosity. Appl. Acoust. 2011, 72, 249-259. [CrossRef]

7. Fatima, S.; Mohanty, A.R. Acoustical and fire-retardant properties of jute composite materials. Appl. Acoust. 2011, 72, 108-114. [CrossRef]

8. Ramis, J.; Alba, J.; Del Rey, R.; Escuder, E.; Sanchís, V.J. Nuevos materiales absorbentes acústicos basados en fibra de kenaf. Mater. Constr. 2010, 60, 133-143. [CrossRef]

9. Ekici, B.; Kentli, A.; Küçük, H. Improving Sound Absorption Property of Polyurethane Foams by Adding Tea-Leaf Fibers. Arch. Acoust. 2012, 37, 515-520. [CrossRef]

10. Del Rey, R.; Berto, L.; Alba, J.; Arenas, J.P. Acoustic characterization of recycled textile materials used as core elements in noise barriers. Noise Control Eng. J. 2015, 63, 439-447. [CrossRef] 
11. Othmani, C.; Taktak, M.; Zain, A.; Hantati, T.; Dauchez, N.; Elnady, T.; Fakhfakh, T.; Haddar, M. Acoustic characterization of a porous absorber based on recycled sugarcane wastes. Appl. Acoust. 2017, 120, 90-97. [CrossRef]

12. Buratti, C.; Belloni, E.; Lascaro, E.; Lopez, G.A.; Ricciardi, P. Sustainable Panels with Recycled Materials for Building Applications: Environmental and Acoustic Characterization. Energy Procedia 2016, 101, $972-979$. [CrossRef]

13. Asdrubali, F.; Pisello, A.L.; Alessandro, F.D.; Bianchi, F.; Cornicchia, M.; Fabiani, C. Innovative Cardboard Based Panels with Recycled Materials from the Packaging Industry: Thermal and Acoustic Performance Analysis. Energy Procedia 2015, 78, 321-326. [CrossRef]

14. Del Rey, R.; Alba, J.; Ramis, J.; Sanchís, V.J. Nuevos materiales absorbentes acústicos obtenidos a partir de restos de botellas de plástico. Mater. Constr. 2011, 61, 547-558. [CrossRef]

15. Rushforth, I.M.; Horoshenkov, K.V.; Miraftab, M.; Swift, M.J. Impact sound insulation and viscoelastic properties of underlay manufactured from recycled carpet waste. Appl. Acoust. 2005, 66, 731-749. [CrossRef]

16. Allard, J.; Champoux, Y. New empirical equations for sound propagation in rigid frame fibrous materials. J. Acoust. Soc. Am. 1992, 91, 3346-3353. [CrossRef]

17. Garai, M.; Pompoli, F. A simple empirical model of polyester fibre materials for acoustical applications. Appl. Acoust. 2005, 66, 1383-1398. [CrossRef]

18. Komatsu, T. Improvement of the Delany-Bazley and Miki models for fibrous sound-absorbing materials. Acoust. Sci. Technol. 2008, 29, 121-129. [CrossRef]

19. Del Rey, R.; Alba, J.; Arenas, J.P.; Sanchis, V.J. An empirical modelling of porous sound absorbing materials made of recycled foam. Appl. Acoust. 2012, 73, 604-609. [CrossRef]

20. Perini, K.; Rosasco, P. Cost-benefit analysis for green façades and living wall systems. Build. Environ. 2013, 70, 110-121. [CrossRef]

21. D'Alessandro, F.; Asdrubali, F.; Mencarelli, N. Experimental evaluation and modelling of the sound absorption properties of plants for indoor acoustic applications. Build. Environ. 2015, 94, 913-923. [CrossRef]

22. Connelly, M.; Hodgson, M. Experimental investigation of the sound absorption characteristics of vegetated roofs. Build. Environ. 2015, 92, 335-346. [CrossRef]

23. Pacheco-Torgal, F. Eco-efficient construction and building materials research under the EU Framework Programme Horizon 2020. Constr. Build. Mater. 2014, 51, 151-162. [CrossRef]

24. Portal Español del Programa Marco de Investigación e Innovación de la Unión Europea. Horizonte 2020. Available online: https: / / eshorizonte2020.es/ (accessed on 3 January 2019).

25. Documento Básico HR Protección Frente al Ruido. Available online: https://www.codigotecnico.org/ images/stories/pdf/proteccionRuido/DccHR.pdf (accessed on 3 January 2019).

26. ISO 10140-5:2010-Acoustics_Laboratory Measurement of Sound Insulation of Building Elements-Part 5: Requirements for Test Facilities and Equipment; International Organization for Standardization: Geneva, Switzerland, 2010.

27. ISO 10140-1:2016 - Acoustics—Laboratory Measurement of Sound Insulation of Building Elements_Part 1: Application Rules for Specific Products; International Organization for Standardization: Geneva, Switzerland, 2016.

28. ASTM E2611-17 Standard Test Method for Normal Incidence Determination of Porous Material Acoustical Properties Based on the Transfer Matrix Method 1; ASTM International: West Conshohocken, PA, USA, 2017. [CrossRef]

29. Kuerer, R.C. Classes of acoustical comfort in housing: Improved information about noise control in buildings. Appl. Acoust. 2002, 52, 197-210. [CrossRef]

30. Huang, L.; Zhu, Y.; Ouyang, Q.; Cao, B. A study on the effects of thermal, luminous, and acoustic environments on indoor environmental comfort in offices. Build. Environ. 2012, 49, 304-309. [CrossRef]

31. Rychtáriková, M.; Muellner, H.; Urban, D.; Chmelik, V.; Roozen, B.; Glorieux, C. Influence of temporal and spectral features of neighbour's noise on perception of its loudness. In Proceedings of the 42nd International Congress and Exposition on Noise Control Engineering, Innsbruck, Austria, 15-18 September 2013; pp. 1408-1415.

32. Hongisto, V.; Mäkilä, M.; Suokas, M. Satisfaction with sound insulation in residential dwellings - The effect of wall construction. Build. Environ. 2015, 85, 309-320. [CrossRef]

33. Rychtáriková, M.; Muellner, H.; Chmelík, V.; Roozen, N.B.; Urbán, D.; Garcia, D.P.; Glorieux, C. Perceived Loudness of Neighbour Sounds Heard Through Heavy and Light-Weight Walls with Equal Rw + C50-5000. Acta Acust. United Acust. 2016, 102, 58-66. [CrossRef] 
34. Godinho, L.; Masgalos, R.; Pereira, A.; Branco, F.G. On the use of a small-sized acoustic chamber for the analysis of impact sound reduction by floor coverings. Noise Control Eng. J. 2010, 58, 658-668. [CrossRef]

35. Piedrahita, Y.; Fajardo, F. Construcción de una cámara anecoica para la caracterización de la pérdida de transmisión sonora. Rev. Bras. Ensino Física 2012, 34, 1-9. [CrossRef]

36. Ricciardi, E.D. Design of a Scaled Down Acoustic Experiment with Anechoic and Reverberation Chambers; The Ohio State University: Columbus, OH, USA, 2013.

37. Linares, N.; Emilio, J.; Ruiz, N.; Miguel, J. Cualificación acústica de una cámara de trasmisión vertical de dimensiones reducidas. In Proceedings of the $46^{\circ}$ Congreso Español De Acústica Encuentro Ibérico De Acústica European Symposium on Virtual Acoustics and Ambisonics, Valencia, Spain, 21-23 October 2015; pp. 756-763.

38. Del Rey, R.; Alba, J.; Bertó, L.; Gregori, A.; Gregori, A. Small-sized reverberation chamber for the measurement of sound absorption. Mater. Constr. 2017, 67, 139. [CrossRef]

39. NOISEFREETEX (LIFE+09 ENV/ES/461). Available online: http://www.fomentex.eu/noisefreetex/ (accessed on 3 January 2019).

40. del Rey Tormos, R.M.; Alba Fernández, J.; Blanes, M.; Molla, K.; Marco, B.; Fallarella, E.; Peruzzi, F.; Sanchis Rico, V.J.; Carrasco, F. Soluciones demostrativas para reducir la contaminación acústica en las áreas industriales mediante la utilización de tecnologías de acabados en los materiales textiles: Proyecto LIFE 09/ENV/ES/000461-NOISEFREETEX. Rev. Acúst. 2013, 44, 3-11.

41. ISO 140-1:1997-Acoustics-Measurement of Sound Insulation in Buildings and of Building Elements—Part 1: Requirements for Laboratory Test Facilities with Suppressed Flanking Transmission; International Organization for Standardization: Geneva, Switzerland, 1997.

42. Torres Romero, J.V. Diseño y Construcción de una Cámara de Transmisión Acústica a Escala. Master's Thesis, Universitat Politècnica de València, Valencia, Spain, 2011.

43. Alba, J.; Del Rey, R.; Torres, J.V.; Bertó, L.; Hervás, C. Cámara de transmisión acústica a escala para el estudio de pantallas acústicas. In Proceedings of the VIII Congreso Iberoamericano de Acústica, el VII Congreso Ibérico de Acústica, el 43 Congreso Español Acústica -Tecniacústica 2012, Évora, Portugal, 1-3 October 2012; pp. 1-11.

44. Everest, F.A.; Frederick, A.; Pohlmann, K.C. Master Handbook of Acoustics; McGraw-Hill: New York, NY, USA, 2009.

45. ISO 10140-4:2010-Acoustics_Laboratory Measurement of Sound Insulation of Building Elements-Part 4: Measurement Procedures and Requirements; International Organization for Standardization: Geneva, Switzerland, 2010.

46. ISO 3382-2:2008-Acoustics-Measurement of Room Acoustic Parameters-Part 2: Reverberation Time in Ordinary Rooms. Available online: https:/ / www.iso.org/standard/36201.html (accessed on 4 March 2017).

47. Bertó Carbó, L. Nuevos Materiales, Modelos y Técnicas de Caracterización en Acústica de la Edificación y Acústica Medioambiental; Universitat Politècnica de València: Valencia, Spain, 2015. [CrossRef]

48. ISO 354:2003-Acoustics-Measurement of Sound Absorption in a Reverberation Room; International Organization for Standardization: Geneva, Switzerland, 2003.

49. Schroeder, M.R. Die statistischen Parameter der Frequenzkurven von grossen Räumen. Acustica 1954, 4, 594-600.

50. Schroeder, M.R.; Kuttruff, K.H. On Frequency Response Curves in Rooms. Comparison of Experimental, Theoretical, and Monte Carlo Results for the Average Frequency Spacing between Maxima. J. Acoust. Soc. Am. 1962, 34, 76-80. [CrossRef]

51. Skålevik, M. Schroeder Frequency Revisited. Forum Acust. 2011, 1965-1968. [CrossRef]

52. Pedersen, D.B.; Roland, J.; Raabe, G.; Maysenhölder, W. Measurement of the Low-Frequency Sound Insulation of Building Components. Acta Acust. United Acust. 2000, 86, 495-505.

53. Roozen, N.B.; Labelle, L.; Rychtarikova, M.; Glorieux, C. Determining Radiated Sound Power of Building Structures by Means of Laser Doppler Vibrometry. J. Sound Vib. 2015, 346. [CrossRef]

54. Roozen, N.B.; Leclère, Q.; Urbán, D.; Kritly, L.; Glorieux, C. Assessment of the Sound Reduction Index of Building Elements by Near Field Excitation through an Array of Loudspeakers and Structural Response Measurements by Laser Doppler Vibrometry. Appl. Acoust. 2018, 140, 225-235. [CrossRef]

55. Roozen, N.B.; Leclère, Q.; Urbán, D.; Echenagucia, T.; Block, P.; Rychtarikova, M.; Glorieux, C. Assessment of the Airborne Sound Insulation from Mobility Vibration Measurements; a Hybrid Experimental Numerical Approach. J. Sound Vib. 2018, 432, 680-698. [CrossRef] 
56. Quintana, A.; Alba, J.; del Rey, R.; Guillén-Guillamón, I. Comparative Life Cycle Assessment of gypsum plasterboard and a new kind of bio-based epoxy composite containing different natural fibers. J. Clean. Prod. 2018, 185, 408-420. [CrossRef]

57. Del Rey, R.; Alba, J.; Crespo, J.E.; Fontoba, J. Estudio de la influencia del tipo de fibra y resina en composites como soluciones ligeras para aislamiento acústico. In Proceedings of the $48^{\circ}$ Congreso Español De Acústica (Tecniacústica 2017) y Encuentro Ibérico De Acústica, A Coruña, Spain, 4-6 October 2017.

58. Wool4build: El Aislante Natural Para Construcciones Sostenibles. Available online: http://www.wool4build. com/ (accessed on 3 January 2019).

59. Del Rey, R.; Uris, A.; Alba, J.; Candelas, P. Characterization of Sheep Wool as a Sustainable Material for Acoustic Applications. Materials 2017, 10, 1277. [CrossRef] [PubMed]

60. Del Rey, R.; Uris, J.; Candelas, P. WOOL4BUILD: Improved isolation material for eco-building based on natural wool. Rev. Acúst. 2017, 48, 3-10.

61. ISO 10140-2:2010-Acoustics_Laboratory Measurement of Sound Insulation of Building Elements-Part 2: Measurement of Airborne Sound Insulation; International Organization for Standardization: Geneva, Switzerland, 2010.

62. Alba, J.; Ramis, J.; Hernández, F. Aisla 3.0.: Herramienta informática para el cálculo del aislamiento acústico a ruido aéreo de configuraciones multicapa con paneles perforados. In Proceedings of the 360 Congreso Nacional de Acústica (Tecniacústica 05), Encuentro Ibérico de Acústica y EAA Symposium, Terrasa, Spain, October 2005.

63. Ookura, K.; Saito, Y. Transmission loss of multiple panels containing sound absorbing materials in a random incidence field. In Inter-noise 78: Designing for Noise Control, Proceedings of the International Conference, San Francisco, CA, USA, 8-10 May 1978; pp. 637-642.

64. Chen, K.T.; Jan, S.H. Sound Transmission Loss of Thick Perforated Panels. Build. Acoust. 2001, 8, 41-56. [CrossRef]

65. Ingard, K.U.; Dear, T.A. Measurement of acoustic flow resistance. J. Sound Vib. 1985, 103, 567-572. [CrossRef]

66. ISO 10534-2:1998 - Acoustics—Determination of Sound Absorption Coefficient and Impedance in Impedance Tubes-Part 2: Transfer-Function Method; International Organization for Standardization: Geneva, Switzerland, 1998.

(C) 2019 by the authors. Licensee MDPI, Basel, Switzerland. This article is an open access article distributed under the terms and conditions of the Creative Commons Attribution (CC BY) license (http:/ / creativecommons.org/licenses/by/4.0/). 